\title{
Georg Simmel and the Study of Religious Conflicts
}

\author{
Chijioke Fidelis Ifezue \\ https://dx.doi.org/10.4314/jrhr.v13i1.16
}

\begin{abstract}
The continuous rise of religious conflicts at different parts of the world has left so many questions unanswered and so many issues unresolved. The quest for supremacy, wealth, relevance and dominance are some of the major causes of religious conflict. Even within religions, there is constant news of conflicts of different kinds, which, unfortunately contrasts with the notion that religion qua religion is one (Madu, 2003). This has also attracted mostly negative attributes to conflict. However, some scholars have taken a different look at the positive side of this negative act - conflict. One of such scholars was Georg Simmel, a German philosopher and sociologist. This work, therefore aims at discussing the scholar Georg Simmel, his ideas and views about conflict in respect to the study of religious conflicts. This work explains how Georg Simmel presented conflict, a negative phenomenon as having some positive outcomes. Seeing religion as a fundamental process in man's life and conflict as a dark tunnel the leads to a bright end of the tunnel, Georg Simmel presents conflict as what the writer terms " a negative beginning with a positive end". To this end, this work shifts ground towards discussing how these bad sides of religious conflicts will be used to achieve something good. As widely believed that something good comes out of bad things, there are different positive roles religious conflict plays, as proposed by Georg Simmel which includes connection, definition, revitalization, social glue, integration and safety valve. For him, all these are necessary for achieving peace and unity only if the conflict is properly handled. Hence, religious conflict is bad in its entirety. Finally, the writer outlines some of the relevance of the work to students, scholars and the general public, advocating for peace.
\end{abstract}


Keywords: Georg Simmel, Conflict, Religious Conflict, Peace.

\section{Introduction}

Most discussions about conflict attract negative connotations. Although one may not be wrong about this approach, nevertheless, it is equally necessary to acknowledge that conflict has some positive characteristics. The positive impact of conflict in human society cannot be swept under the carpet. Tensions and conflicts arise when resources, status, and power are unevenly distributed among groups in society and conflict becomes the engine for social change. In this context, power can be understood as control of material resources and accumulated wealth, control of politics and the institutions that make up society, and one's social status relative to others (determined not just by class but by race, gender, sexuality, culture, and religion, among other things). Conflict theory and its variants are used by many sociologists today to study a wide range of social problems, which includes religious conflict, the main focus of this work.

This work takes a look at Georg Simmel, one of the brains behind sociology and his ideas about conflict, relating such ideas to religious conflict. It also emphasizes mainly on the positive effects of conflict to the society and other institutions, especially, religion. As Georg Simmel believed that conflict and harmony are two sides of a form that are always linked together, hence, conflict, whether religious, political, social and/or economic are sometimes necessary for a constructive society. To achieve this, the present researcher used secondary sources for data collection and presentation and applied conflict theory. This work explains religious conflict and how it has become tools for achieving peace and unity. It also outlined Georg Simmel's five basic positive functions which conflict serves. These include connection, definition, revitalization, social glue, integration and safety valve. The relevance of this study to scholars, students and contemporary society is equally discussed. 


\section{Georg Simmel}

Georg Simmel was a German philosopher and sociologist, who lived between 1858 and 1918. While some hail him as the founder of modern sociology, others see in him only a brilliant stylist who made no original contribution and failed to develop a systematic theory. His wide interests in philosophy, sociology, art, and religion contrasted sharply with those of his more narrowly disciplined colleagues. Eschewing pure philosophy, he preferred to apply it functionally as the philosophy of culture, of money, of the sexes, of religion, and of art. Simmel was sensitive to the intellectual currents of his time and reflected most of them in his work without identifying himself exclusively with any one of them. His methodology is fashioned according to Kantian principles, but with modifications. He was influenced by Hegel, Schopenhauer, and Nietzsche, and his philosophy of life - foreshadowing modern existentialism - has noticeable affinities with the work of his friend Husserl and of Bergson. The theory of duality also appeared in most of his work, especially between individual and society.

The quintessential outsider, Simmel never developed what could be called "a school of thought." But his ideas have heavily influenced a vast array of scholars including renowned sociologists like Norbert Elias and Robert Park, the great European philosophers Martin Heidegger and Martin Buber, as well as the Frankfurt School of Critical. He remains one of the most creative, wide-ranging, and prescient thinkers in social theory and, because of this, his writings continue to inspire. His thoughts on conflict in social institutions likereligion have portrayed conflict to be of positive impact, if properly managed. This has made his idea about conflict very interesting to discuss. 


\section{Study of Religious Conflicts and Simmel's Notion of Conflict}

Conflict is regarded as state of disharmony or disagreement between two or more oppositions which can arise in any social institution, religion inclusive. Hence, religious conflict, according to Gotan (2004) is a conceived interaction in which two or more religious adherents engage in mutually opposing action and use coercive behaviour to destroy, injure, thwart or otherwise control their opponents. Simply put, religious conflict is a situation in which religious adherents are involved in a serious disagreement or argument with one religious group and another. This is a situation in which there are oppositions in ideas, opinions, feelings and wishes. All religions have their accepted dogma, or articles of belief that followers must accept without question. This can lead to inflexibility and intolerance in the face of other beliefs. Therefore, conflict can arise over whose interpretation is the correct one, a conflict that ultimately cannot be solved because there is no judge. However, those followers must also be motivated to action. Although, almost invariably, the majority adherents of any faith hold moderate views, they are often more complacent, whereas extremists are motivated to bring their interpretation of God's will to fruition, whether it leads to conflict or not is least of their concern. Little (1996) argues that some religious groups consider violence a point of duty, paying less attention to the consequences of their actions. Ironically, conflict, be it religious or otherwise, is a very necessary tool whereby coexistence could be possible in any society.

Georg Simmel's works on religion as a fundamental process in human life laid the foundation for this discourse, especially as it concerns religious conflict and his reflections on religion and its relation to modernity, personality, art, sociology, psychology, philosophy, and science. The characteristic doctrines of his thought as applied to religion, based on phenomenological analysis of human experience that emphasizes the subjective dimensions of life cannot 
be neglected, when discussing issues like conflict. Simmel (1955) did a lot of remarkable works on conflict in society. Though his reasoning often appears complicated, yet, it is quite profound. He supported the view that there is no society or institution without conflict and the idea that there must be conflict in order to reach unity or change is something that is a timeless concept as well. He viewed conflict as the opposition of one individual element in the same association to another which is by no means a merely negative social factor, but in many ways the only means through which coexistence with individuals intolerable in themselves could be possible. Hence, opposition, for him, is an integrating component of the relationship itself. Although he concentrated more on conflict in the society, such ideas can also be applied to religious conflict, since religion is one of the major social institutions.

He was one of the first to study conflict as a social phenomenon. As a social phenomenon, conflict may range from the use of physical force to litigation to intimidation through threat of physical harm. The aim of conflict, as well as the aim of competition is to win and by any means necessary. However, depending on the level of force used, the result may be the actual destruction of adversaries. Using the major conflicts witnessed in the northern part of Nigeria as an example, it is very obvious that the outcome is not far from destruction of adversaries.

Georg Simmel's research on social interactions revealed that the number of participants in the interaction is key in determining the nature of that interaction. He described the interactions within a "dyad", with two participants, a "triad" of three participants, and the differences between interactions within small and large groups of participants. Here, he was able to point out that as long as there is an interaction between two or more individuals, conflict is unavoidable. He argued that conflict is inseparable from social interaction and often used the word "sociation" which refers to the pattern or form 
that a particular social interaction assumes. That is, a mode or process of social interaction, whether associative or dissociative, positive or negative. For example, the smallest social phenomenon takes place between two individuals, to the bigger social institution like religion, the level of sociation intensifies. That is, the more frequent the interaction, the more occasions for hostile interaction. However, frequent occasions for conflict do not necessarily result in frequent conflicts. This is because the closeness of relationship and the strong mutual attachment may induce parties to avoid conflict. As stated previously, when conflict does occur, it is likely to be intense. However, conflict has the potential to re-establish unity. Much depends on the issues that are at stake in conflict and the type of social structure in which conflict occurs. In religion, such struggle over dogmatic supremacy, indoctrination, quest for political relevance and so on may sometimes determine if the end point of the conflict will turn out positively or not. There is a distinction to be made between conflicts over basic matters of principle and conflicts over less central issues. In so far as conflict resolves tension between antagonists. it can serve to integrate relationships. However, conflict tends to serve this positive function only when it concerns interests or values that do not contradict the basic assumptions upon which the relation is founded. Unfortunately, the Nigeria's major religious conflicts between Christianity and Islam have not always turned out good. The same could be said about intra-religious interactions which may turn out bad and lead to the breaking off of a new sect from the main body. The number of Christian sects all stemming from a single source attests to the frequency of such conflict (Coleman, 1956). Simmel always took a logical and dualistic approach, bringing out the dynamic interconnectedness and the conflicts between the social units he analyzed. To Simmel, sociation always involves harmony and conflict, attraction and repulsion, love and hatred. It is always the 
result of both categories of interaction; both are positive ingredients, structuring all relationships and giving them enduring form.

\section{Religious Conflict as a Necessary Tool for Peace and Unity}

Edles and Appelrouth (2010) describe conflict as being necessary for "the development of the self and at the same time creation of group unity" (p.288). In order words, conflict is necessary in order to help the individual realize their individuality. Simmel believed that conflict is necessary for unity, which can also lead to social change. He opposed the view that conflict was destructive, choosing to see conflict as positive, with the ability to strengthen social relations. He followed an organismic world view, rather than the Marxian material determinism (mechanistic view). For him, any social system, or social grouping, is designed to create and resolve dualisms or conflicting interests. Using the disease in the human body, he compared his notions of conflict and its positive outcome. Just as disease is the first step in correcting one's health, so conflict is functionally positive to correcting problems in society. This is analogous to the biological building up of antibodies in the human system in order to fight off new diseases. Antibodies are present because an individual has been sick before. When a social institution such as religion is threatened, it leads to maintaining religious boundaries, it defines values and morals and group ties are strengthened as conflict is resolved.

From the above standpoint, the outcome of religious conflict also can be positive, just as Simmel on social conflict. He outlined the five basic positive functions which conflict serves. These are connection, definition, revitalization, social glue, integration and safety valve.

1. Conflict as a Form of Connection: Any interaction between groups or individuals also involves connection and conflict. Simmel (1955) opined that conflict is a basic form of exchange and interaction. A quest for religious dominance between two different 
religious groups in a society, intra-religious struggle for relevance between members and the persecution of religious bodies by the secular world which may lead to conflict, also connects these opposites. Conflict provides a basic way of asserting one's relationship with another person and or, one's religious relationship with another. Among groups, conflict maintains a form of negotiation. Within groups it does so, by releasing tensions among members that might harm the group. One of the hallmarks of professional conduct is that persons who do not like one another personally can nonetheless, work together. With this connection, better means will be devised to reach a consensus or achieve relative peace.

2. Conflict and Identity/Boundary Definition: Identity is one of the several fundamental human needs that underlie many intractable conflicts. Conflict over identity occurs when a person or group feels that his or her sense of self; who one is, is threatened, or denied legitimacy or respect. Conflict among groups sharpens their exterior boundaries. It heightens the sense of "us" versus "them". Within groups conflict focuses the differences between ranks and social levels, just as a religious member is striving to reach higher rank, for example in the church, so as to demonstrate his or her power and decision making ability in the church's authoritative body. This will, in turn encourage hard work and improve initiatives and ideas.

\section{Conflict and the Revitalization of Norms/Traditions/Mores:}

Conflict among groups revitalizes traditions and norms. When conflict occurs in religion, an institution regarded as the hub for virtues and mores, it propels it to renew and strengthen its norms and morals. Within religious groups, the adherents are confronted with an opportunity to recommit themselves to the values that underlie membership in the group. As they are looked up to as role models who should uphold virtues, they will do everything possible to 
channel that negativity in positivity; failure is an option. Man is naturally religious; hence he should strive to pursue those positive attributes associated with religion, even when faced with conflict.

4. Conflict as Social Glue. Group cohesion may be strengthened as much, if not more, by an internal threat. In some cases, conflict, according to Brahm (2004) can provide a safety-valve to allow a group to clear the air in a less destructive way than might otherwise occur. Each conflict is a push away from one party and toward other parties. It can lead to creation of associations or coalitions for which there is no "positive" incentive. In a community with multiple, crisscrossing associations and coalitions alliances along one major line of cleavage can be prevented. The different groups and organisations in religion with differing opinions and ideas often conflict over power, relevance, dominance or space, but by the time such conflict is resolved, it has strengthened united them the more.

5. Conflict as an Integrative Force: Although conflict may seem as a negative phenomenon, it is, on the other hand, an integrative force through which coexistence with individuals intolerable in themselves could be possible. That conflict occurs means that there is disharmony and discord among the different religious groups which weakens its foundation. Simmel (1903) believed that opposition is an integrating component of the relationship itself; it is not merely a means of conserving the total relationship, but it is one of the concrete functions in which the relationship in reality consists. For him, less violent conflicts promote solidarity, integration and orderly change of the system and if constructively handled, can lead to long-term peace and cooperation capable of uniting and forming a strong whole. It is no news that different religious groups experience internal conflicts but yet they resolve it within themselves. For example, the Christian Association of Nigeria (CAN) that governs all the Christian in the 
country is often faced with internal conflicts and disagreements, yet at the end, they resolve it and stand as one. This is also applied to other religious organisations.

\section{Contemporary Relevance of George Simmel's Notion of Conflict}

Firstly, this study focusing on the positivity of religious conflicts informs the contemporary society, scholars and students that conflict can serve as an element of socialization and group formation. Coser (1956) supported and explored the ideas set forth by Georg Simmel and analysed conflict in terms of interactive processes and depicts conflict as "a form of socialization" (p. 31). No group can be entirely harmonious, for then it would lack process and structure. Group formation is a result of both association and dissociation, so that both conflict and cooperation serve a social function. In religion, certain degree of conflict is an essential element in group formation. However, the way a conflict is handled is very important because it may make or mar the institution or group concerned. The present researcher believes that one of the main evidence of such group formation and socialization in Nigeria is the presence of different religious organisations or ruling bodies, like the Christian Association of Nigeria (CAN) and Muslim Association of Nigeria (MAN) among others.

Secondly, religious institutions and the society as well are meant to understand that conflict often revitalizes existent norms and creates a new framework of rules and norms for the contenders. There are cases where the very act of entering into conflict establishes relationships where none previously existed. Once relations have been established through conflict, other types of relations are likely to follow. This is because conflict often leads to the modification and creation of laws as well as the growth of new institutional structures to enforce these laws. The presence of antagonistic behaviour makes people aware of the need for basic norms to govern the rights and 
duties of citizens. The resulting creation and modification of norms makes readjustment of relationships to changed conditions possible. However, this is possible only if there religious groups should understand that they have key roles to play in living by examples and upholding those rules and norms. The difference between man and other animals is rules, without them, man is just an animal.

Thirdly, the study lends credence to the fact that conflict also has the potential to re-establish unity and promote peace. Obi (2012) opines that peace is not a condition but a process that involves stages interaction and conflict. The more frequent the interaction, the more occasions for hostile interaction because of the different individuals or groups with divergent beliefs and ideologies involved. However, frequent occasions for conflict do not necessarily result in frequent conflicts. This is because the closeness of relationship and the strong mutual attachment may induce parties to avoid conflict and promote peace. As stated earlier, when conflict does occur, it is likely to be intense. Much depends on the issues that are at stake. But efforts are made by parties involved and the external bodies to find solutions and re-establish peace. Simmel believed that conflict can help integrate and stabilize a society and that the intensity of the conflict varies depending on the emotional involvement of the parties, the degree of solidarity within the opposing groups, and the clarity and limited nature of the goals. Resolving conflicts can reduce tension and hostility and can pave the way for future agreements

Conflict itself resolves the tension between contrasts. The fact that it aims at peace is only one, expression of its nature. Studying the nature of religious conflict and ways to resolve them is important, especially, in terms of the overall threat that it poses to societal peace and progress 


\section{Conclusion}

Simmel's idea of conflict largely agrees to the saying that if you are ready for peace, you should first prepare for war. He has been able to shift attention to the other side of conflict- a negative phenomenon with positive outcome. Something good comes out of even bad things. Conflict is regarded as being bad, but from the discussions above, it brings about something good afterwards. The writer is not of the opinion that conflict should be encouraged, rather, when conflict occurs, it is pertinent to make good out of it. The challenge is to realize the benefits of conflict in such a way so as to minimize the many costs also associated with it. Conflict tends to be dysfunctional only for social structures in which there are insufficient toleration and the capacity to handle it constructively. Although Nigeria is a pluralistic nation, religious conflicts can still be managed through constructive dialogue, tolerance, obedience to social rules and norms, and above all, imbibing that mindset in the adherents that religion qua religion is one, and that these religious systems are just different routes to the same destination, the transcendental world.

Other fields of study are interested in religion because as Turner (2010) puts it, "it is assumed to contain the seeds of social life as such" (p. 20). Without religion, the world is never the same. Motak (2014) maintains that Simmel attempted to reveal the common root of both social as well as religious phenomena: a drive for unity which is the most powerful integrating factor. Ironically, most reasons for these religious conflicts are about the Supreme Being, the Prince of peace. In a nutshell, scholars and students should preach, teach and encourage peace, as there is no alternative to it! Conflict is a fundamental challenge to every society that should be avoided. There is need to see and act through this lens in identifying conflict as not being bad in its entirety but has some positive attributes, only if properly managed. 


\section{References}

Coleman, J. (1956). Social cleavage and religious conflict. Journal of the Society for Psychological Study of Social Issue, 12, 3, 44-56.

Coser, L. (1956).The functions of social conflict. New York: The Free press.

Edles, L. \& Appelrouth, S. (2010). Sociological theory in the classical era. Los Angeles: Pine Forge.

Gotan, C. (2004). The concept of peace and justice: The Nigerian experience. Jos: Fab Anieh.

Little, D. (1996).Religious militancy: Managing global chaos. Washington DC: USIP.

Madu, J. (2003). The paradox of the "one" and the "many" in religion. Nkpor: Globe.

Motak, D. (2014). Religion and monetary culture in the sociology of Georg Simmel. In A. Mckinnon \& M. Trzebiatowska (Ed.). Sociological theory and the question of religion (pp129-150). United Kingdom: Ashgate.

Obi, H. (2012). The concept of peace. In U. Ughamadu (ed.). Synopsis of peace and conflict studies in West Africa (pp 1-19). Awka: Fab Anieh.

Simmel, G. (1955). Conflict and the web of group affiliations. New York: The Free press.

Turner, B. (2010). Introduction: Mapping the Sociology of Religion. In B. Turner (ed.).The New Blackwell Companion to the Sociology of Religion (pp. 1-29). Oxford: Wiley-Blackwell.

Chijioke Fidelis Ifezue is a postgraduate student in Department of Religion and Human Relations, Nnamdi Azikiwe University, Awka, Nigeria. 